\title{
Effect of aeration rates on the composting processes and Nitrogen loss during composting
}

\author{
Zhi-Qiang Xiong ${ }^{1}$, Guo-Xing Wang ${ }^{1}$, Zhao-Chen Huo ${ }^{1}$, Lei Yan ${ }^{1}$, Ya-Mei Gao ${ }^{1}$, Yan-Jie Wang ${ }^{1}$, Ji-Dong Gu ${ }^{2 *}$ and Wei-Dong \\ Wang $^{1 *}$ \\ ${ }^{1}$ Heilongjiang Provincial Key Laboratory of Environmental Microbiology and Recycling of Argo-Waste in Cold Region, College of Life \\ Science and Technology, Heilongjiang Bayi Agricultural University, Daqing 163319, China \\ ${ }^{2}$ Laboratory of Environmental Microbiology and Toxicology, School of Biological Sciences, The University of Hong Kong, Pokfulam \\ Road, Hong Kong, China
}

\begin{abstract}
Composting is a controlled biological process used to stabilize and transform waste into a soil treatment. Aeration rate is one factor that controls the process of composting, as it ensures the growth of adequate aerobic microbe populations. To investigate the effect of aeration rates on the physicochemical indexes of compost and the loss of nitrogen content during composting, aerobic composting processes with different aeration rates (A: $0.2 \mathrm{~L} / \mathrm{min} / \mathrm{kg}$ TS, B: $0.05 \mathrm{~L} / \mathrm{min} / \mathrm{kg}$ TS and C: $0 \mathrm{~L} / \mathrm{min} / \mathrm{kg}$ TS) were studied. Ammonium-nitrogen, nitrate nitrogen, total nitrogen and other factors in compost samples from different periods were measured. The results showed that aeration rate significantly affected $\mathrm{O}_{2}$ content under different conditions. The aeration rate also significantly affected water content, nitrate nitrogen, and nitrogen loss. $\mathrm{NH}_{3}$ emissions increased as aeration rates increased at high temperatures owing to nitrogen loss. These results showed that aeration rate had a significant effect on total nitrogen and ammonia emissions $(\mathrm{p}<0.05)$. Thus, optimization of the ventilation method could significantly increase seed germination rate.
\end{abstract}

Keywords: manure composting, aeration rates, nitrogen loss, $\mathrm{NH}_{3}$, oxygen gas

* Correspondence to:

Wei-Dong Wang, College of Life Science and Technology, Heilongjiang Bayi Agricultural University, Daqing 163319, China; E-mail: wwdcyy@ 126.com Ji-Dong Gu, School of Biological Sciences, The University of Hong Kong, Pokfulam Road, Hong Kong, China; Email: jdgu@ @ku.hk

Received: August 6, 2017; Accepted: September 9, 2017; Published Online: September 26, 2017

Citation: Xiong, Z.Q., Wang, G.X., Huo, Z.C., Yan, L., Gao, Y.M., Wang, Y.J., Gu, J.-D. and Wang, W.D., 2017, Effect of aeration rates on the composting processes and Nitrogen loss during composting. Applied Environmental Biotechnology, 2(1), 20-28. http://doi.org/10.26789/AEB.2017.01.003.

Copyright: Effect of aeration rates on the composting processes and Nitrogen loss during composting @ 2017 Zhi-Qiang Xiong et al.. This is an Open Access article distributed under the terms of the Creative Commons Attribution-Noncommercial 4.0 International License, permitting all non-commercial use, distribution, and reproduction in any medium, provided the original work is properly cited and acknowledged.

\section{Introduction}

The amount of cattle waste generated in China has increased dramatically with the rapid development of cattle farms. Manure is an important component of agricultural waste but is not properly treated: it is directly discharged into the environment and produces hygiene hazards, odor pollution, ground and surface water pollution due to the leaching of pollutants. Composting is considered an important process by which agricultural organic wastes can be stabilized through the degradation of biodegradable components by microbial communities (El-Nagerabi et al., 2012; Zeng et al., 2011). This process involves a significant loss of nitrogen (Gu et al., 2011).

During the aerobic composting of poultry waste/straw stalks, sludge/straw stalks and poultry waste/sawdust, the total $\mathrm{N}$ loss can be $16-76 \%$ (Gu et al., 2011). The emission of $\mathrm{NH}_{3}$ will produce a compost product that has low nitrogen content, diminishing its value as a fertilizer. During composting, 9.6-46\% of the initial TN loss of raw materials is in the form of $\mathrm{NH}_{3}$ emissions (Jiang et al., 2011). Most previous studies have reported that $\mathrm{NH}_{3}$ emission increases with increasing aeration rates (Jiang et al., 2011; Shen et al., 2011; Wu et al., 2011). This suggests that the aeration rate has a significant influence on the production and emission of $\mathrm{NH}_{3}$ (Ahn et al., 2011; Shen et al., 2011).

The aeration rate may directly affect the quality of the compost product, loss of nitrogen, and energy consumption. Insufficient aeration can lead to anaerobic conditions due to the lack of oxygen, while excessive aeration can increase costs and slow down the composting process via loss of heat, water, and ammonia, causing loss of nitrogen. The maintenance of appropriate oxygen content during composting would limit the formation of anaerobic zones and thereby avoid the generation of intermediate products of anaerobic metabolism (Scaglia et al., 2011). Therefore, it is not known whether the optimal values of aeration rate will lead to minimal loss of nitrogen.

The seed germination test is one common method used to evaluate compost maturity for further agricultural application (Bes et al., 2013). Several factors during the composting process could have an impact on compost maturity, such as aeration rate, $\mathrm{pH}$, initial total ammonia nitrogen content and others (Grunditz and Dalhammar, 2001; Guo, et al., 2012). However, the effects of these factors of compost have not been examined systematically. In particular, the effect of aeration rate has not been examined. 
Table 1. Property of raw materials for composting $(\bar{X} \pm \mathrm{SD})$

\begin{tabular}{lcccccc}
\hline Material & $\mathbf{p H}$ & Water Content $(\%)$ & TOC & & TN & \multirow{2}{*}{ C/N ratio } \\
Cow & 8.2 & $69.28 \pm 2.37$ & $362.35 \pm 10.14$ & & $22.61 \pm 7.13$ & 16.02 \\
Turf grass & 8.3 & $8.40 \pm 1.56$ & $407.15 \pm 7.87$ & & $7.71 \pm 8.35$ & 52.81 \\
Mixture & 8.2 & $64.28 \pm 2.73$ & $382.35 \pm 11.04$ & & $19.61 \pm 7.13$ & 19.5 \\
\hline
\end{tabular}

This experiment, using cow dung and turf grass as the main raw materials, using $0.2 \mathrm{~L} / \mathrm{min} / \mathrm{kg}$ TS (treatment $\mathrm{A}$ ), $0.05 \mathrm{~L} / \mathrm{min} / \mathrm{kg}$ TS (treatment B) and $0 \mathrm{~L} / \mathrm{min} / \mathrm{kg}$ TS (treatment $\mathrm{C}$ ) as its three aeration rate treatment conditions, simulated the cow dung composting process. We sampled and measured the temperature, water content, $\mathrm{pH}$, ammonium, nitrate, $\mathrm{NH}_{3}$ and other physical and chemical parameters at different times during the composting process. Meanwhile, we also measured the content and the variation of $\mathrm{O}_{2}$ in the compost pile. We explored how different aeration rates changed nitrogen content during manure composting. During the manure composting process, we set and regulated a reasonable aeration rate to reduce the loss of nitrogen and to lay the foundations for future study.

\section{Materials and Methods}

\subsection{Composting Experimental Materials and Treatment}

The experimental materials used were cow dung and turf grass (Table 1). Turf grass was used to adjust the initial $\mathrm{C} / \mathrm{N}$ ratio of the composting material. Cow dung was collected from the surrounding countryside in Daqing, China. Turf grass was collected from a residential area of Heilongjiang Bayi Agricultural University.

The cow dung was uniformly mixed with turf grass at a $1: 1$ volume ratio. The water content of the mixture was adjusted to approximately $65 \%$, after which the mixture was put into three fermentation boxes (volume of $0.216 \mathrm{~m}^{3}, 0.6$ $\mathrm{m}$ long, $0.6 \mathrm{~m}$ wide and $0.6 \mathrm{~m}$ high). The starting weight of material was $60 \mathrm{~kg}$ in each box.

\subsection{Device and Methods}

Figure 1 is a schematic diagram of the experimental device. A fermentation room and a control system were included in this composting device. The fermentation room was made of steel and had ventilation screens at the bottom and an insulating layer in the wall. The ventilation control system contained a flowmeter and an air compressor. When the pressure fell below a set value, the ventilation control system could automatically control the air compressor, ensuring the stability of the ventilation rate. The air tester could test the properties of gases.

During the composting process, experiments were set up under three aeration rates (treatment A: $0.2 \mathrm{~L} / \mathrm{min} / \mathrm{kg} \mathrm{TS}$;

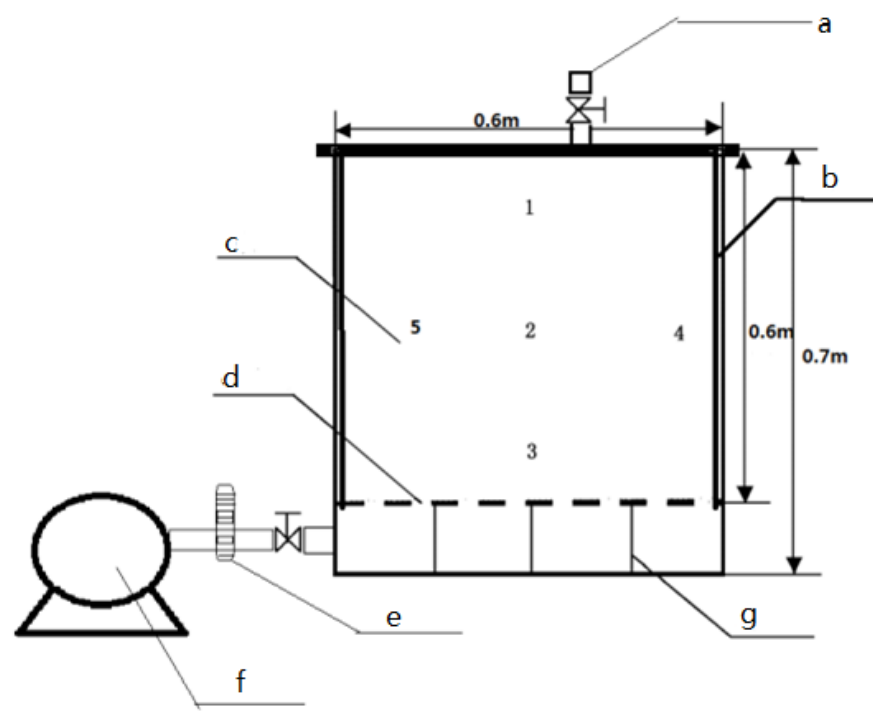

Note: (a) air tester and sealing cover; (b) insulating layer; (c) fermenting room; (d) wire grilling; (e) flowmeter; (f) air compressor; (g) separation wall. Numerical numbers $(1,2,3,4$, and 5) for sampling points

Figure 1. The construction of manure composting

treatment B: $0.05 \mathrm{~L} / \mathrm{min} / \mathrm{kg}$ TS; and treatment C: $0 \mathrm{~L} / \mathrm{min} / \mathrm{kg}$ TS). After 6 days, the compost piles were plowed (the material in the center of the pile was thoroughly consumed, requiring that the material be fully re-blended). The material was not compacting completely and had air gap. The reactor was usually not sealed with the cover completely. Only when measuring gas, the reactor was sealed with the cover completely.

The composting process proceeded for 60 days. At 0 , $1,2,3,5,7,14,21,28,35$ and $60 \mathrm{~d}$, the $\mathrm{O}_{2}$ content and $\mathrm{NH}_{3}$ emissions of the piles were measured. Samples which was about $200 \mathrm{~g}$ were collected using multi-point sampling; those not immediately analyzed were stored at $4^{\circ} \mathrm{C}$ until they were assessed for total carbon, total nitrogen, water, $\mathrm{NH}_{4}^{+}-\mathrm{N}$ and $\mathrm{NO}_{3}^{-}-\mathrm{N}$ content and $\mathrm{pH}$. Each treatment was replicated 3 times.

\subsection{Determination of Indicators and Methods}

The compost pile temperature was monitored by inserting a Digital Thermometer (UT325, China) into the center of the composting material at 13:00 every day. 
$\mathrm{O}_{2}$ content was monitored by inserting a gas detector (GT901-O ${ }_{2}$, China) into five different locations (up, down, left, right and center) at 13:00 every day and then calculating the average of the five readings.

$\mathrm{NH}_{3}$ emissions were measured using a washing bottle with boric acid titrated against $\mathrm{H}_{2} \mathrm{SO}_{4}$ at 13:00 every day. The fermentation box was sealed with a sealing cover that had an air outlet port. Released gas was absorbed by $0.05 \%$ boric acid liquid. After 1 hour, 2 to 3 drops of methyl red methylene blue mixed indicator were added to the absorbing liquid and titrated with $0.025 \mathrm{~mol} \mathrm{H}_{2} \mathrm{SO}_{4}$ standard liquid.

To determine $\mathrm{pH}$ value, a fresh sample of compost was mixed with deionized water (1:10), shaken at $200 \mathrm{rpm}$ for $30 \mathrm{~min}$, and then filtered by vacuum filter. The $\mathrm{pH}$ of the filtrate liquid was measured with a small $\mathrm{pH}$ detector B-212 (HORIBA, Japan).

Water content was determined by the constant weight method. First, a petri dish was weighed after drying to constant weight; fresh compost was then added to the dish and the dish containing compost was weighed. Then, the dish and compost were placed overnight in a drying box in an oven at $100^{\circ} \mathrm{C}$, then removed to a desiccator to cool to room temperature and then weighed. The water content was calculated as follows: water content $=$ (weight difference between the sample before and after being dried / weight of sample before drying) $\times 100 \%$.

Ammonium-nitrogen $\left(\mathrm{NH}_{4}^{+}-\mathrm{N}\right)$ and nitrate-nitrogen $\left(\mathrm{NO}_{3}^{-}-\mathrm{N}\right)$ content were determined by the $\mathrm{KCl}$ extractionindophenol blue colorimetric method and the spectrophotometric method with phenol disulfonic acid (Sims et al., 1995), respectively.

Total nitrogen (TN) was measured by the Kjeldahl method according to the Chinese national standard for organic fertilizer (NY 525-2012). The sample was completely dissolved in a mixed acid, diluted, filtered and distilled, and finally titrated with boric acid solution. The total nitrogen loss rate during composting $=\left(\mathrm{m}_{\text {starting }} \cdot \rho_{\text {start }}-\mathrm{m}_{\text {end }} \cdot \rho_{\text {end }}\right)$ $\times 100 \% /\left(\mathrm{m}_{\text {starting }} \cdot \rho_{\text {start }}\right)$, wherein $\mathrm{m}_{\text {starting }}$ and $\mathrm{m}_{\text {end }}$ are the total mass of raw materials and the total mass of the compost sample at the end, respectively, and $\rho_{\text {start }}$ and $\rho_{\text {end }}$ are the corresponding total nitrogen contents.

The TOC of the dried samples was measured using a TOC/TN analyzer (multi N/C @2100, Jena, Germany), we analyzed the TOC of the dried samples.

To test seed germination, two qualitative filter papers were put into petri dishes that were $9 \mathrm{~cm}$ in diameter, 10 test seeds (which were the same size and had a similarly plump shape) were evenly spaced on the filter paper, and 5 $\mathrm{mL}$ leaching liquor was pipetted into the petri dishes (deionized water as $\mathrm{CK}$ ). After culturing the seeds in the dark at $30^{\circ} \mathrm{C}$ for $48 \mathrm{~h}$, we recorded the seed germination rate and measured the root length. Each treatment was replicated 3 times. The test seeds were cucumber seeds, the germination rate of the test seeds was above $90 \%$, and root morphological characteristics and length were easily measured. According to the following formula, we calculated the relative germination rate (RGP) of seeds, relative root elongation (RRE) and germination index (GI).

RGP $(\%)=$ average germination rate of treatment $\times$ 100/average germination rate of CK

RRE $(\%)=$ average root length of treatment $\times 100$ /average root length of $\mathrm{CK}$

$\mathrm{GI}(\%)=\mathrm{RGP} \times \mathrm{RRE}$

Significance was tested using SPSS 19.0 software to express the impact of different aeration rates on the nitrogen content of the compost. Figures were created using Origin 9.1 (OriginLab, USA).

\section{Results and Discussion}

\subsection{Temperature and $\mathrm{O}_{2}$ Content}

The temperature during the composting process is an important indicator of whether the compost is decomposed well. The temperatures of the compost under the three treatments were above $50^{\circ} \mathrm{C}$ on the second day (Figure 2). The maximum temperature of the compost under treatment $\mathrm{B}$ was $60^{\circ} \mathrm{C}$. Compost under treatment A lost a large amount of heat because it had the highest aeration rate; the hightemperature phase for treatment A lasted four days, but for treatments B and C this phase lasted five days. Accordingly, all three compost piles achieved compost hygiene indicators (GB 7959-1987) (Yu et al., 2007). The compost produced under treatment A lost significantly more heat than did the composts produced under treatments $\mathrm{B}$ or $\mathrm{C}$. In the mature stage, the temperature difference among treatments was not significant.

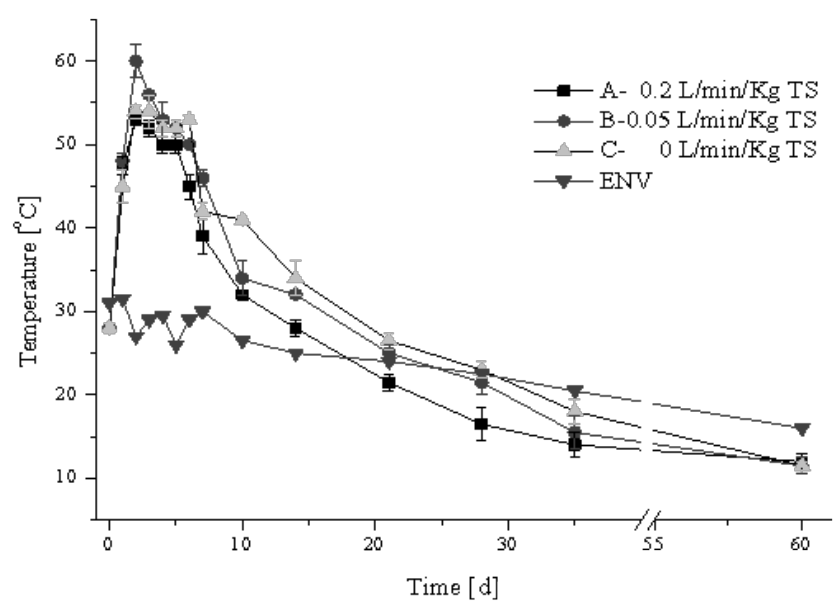

Note: ENV, environment; A, treatment A $(0.2 \mathrm{~L} / \mathrm{min} / \mathrm{kg} \mathrm{TS}) ; \mathrm{B}$, treatment B $(0.05 \mathrm{~L} / \mathrm{min} / \mathrm{kg} \mathrm{TS})$; C, treatment C (0 L $/ \mathrm{min} / \mathrm{kg} \mathrm{TS})$.

Figure 2. Changes of temperature during composting

But the statistical analysis showed that the aeration rate had a significant influence on the change in temperature in the high-temperature period. Guo et al. (2012) also found this rule.

The change in the $\mathrm{O}_{2}$ content of the composts essentially followed the same trend for each treatment (Figure 3). The lowest $\mathrm{O}_{2}$ content was observed on the third day for all treatments. The minimum $\mathrm{O}_{2}$ contents for treatments $\mathrm{A}, \mathrm{B}$ and $\mathrm{C}$ were $14.10 \%, 11.26 \%$ and $5.19 \%$, respectively. On 
the ninth day, when the high-temperature period was completely over, the $\mathrm{O}_{2}$ content for each treatment increased to $19.90 \%, 18.44 \%$ and $9.21 \%$, respectively. Then, the $\mathrm{O}_{2}$ content of each pile increased to approximately $20.0 \%$ and remained stable until the end of the study. Jiang et al. (2011) and Guo et al. (2012) also found that as the composting temperature became close to the ambient temperature, the oxygen content returned to $20-21 \%$. The reason was that along with composting, the pile became more loosened to let more $\mathrm{O}_{2}$ gas into the compost pile. In a study of the aerobic composting of manure (Gao et al., 2007), high levels of microbial activity were detected when the air was constantly replenished from the cross-sectional distribution during the heating period and the high-temperature period; meanwhile, $\mathrm{O}_{2}$ was continuously consumed, so the $\mathrm{O}_{2}$ content of each pile decreased. The $\mathrm{O}_{2}$ content of the compost produced under treatments $\mathrm{A}$ and $\mathrm{B}$ could be adapted to the requirements of aerobic composting because the ventilation was sufficient. At the beginning of the 30 days, the impact of the three different aeration rates on $\mathrm{O}_{2}$ content was remarkable $(\mathrm{p}<0.05)$.

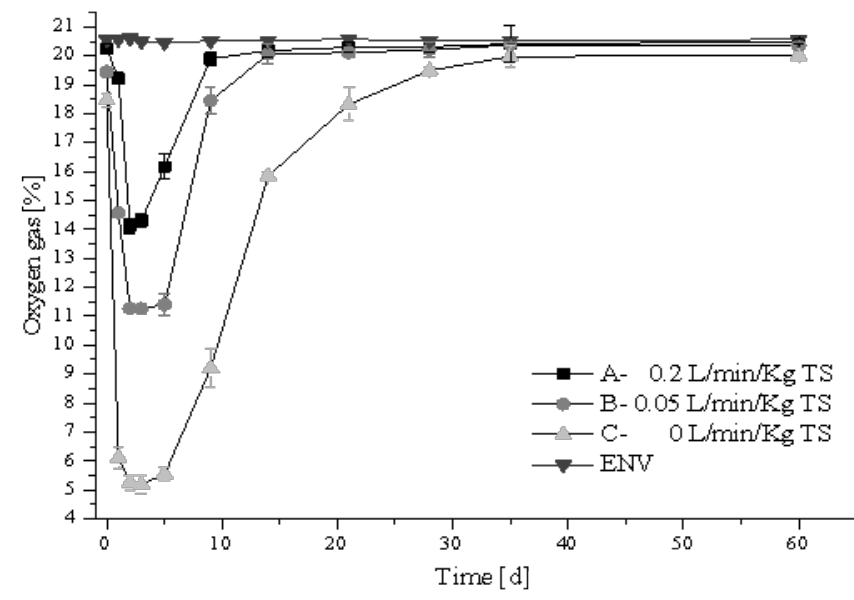

Figure 3. Changes of $\mathrm{O}_{2}$ content during composting

\section{2. $\mathrm{pH}$ and Water Content}

During the entire composting process, the $\mathrm{pH}$ of each treatment was above 7.4 (Figure 4), which was in the range of 6.0-9.0 that is recommended for rapid composting. Figure 4 shows that during the warming period, the $\mathrm{pH}$ of the compost produced under treatments $\mathrm{A}, \mathrm{B}$, and $\mathrm{C}$ decreased to $8.03,8.03$, and 7.5 , respectively; the $\mathrm{pH}$ for each treatment increased to approximately 8.5 during the high-temperature phase. The $\mathrm{pH}$ of the compost produced under treatment $\mathrm{C}$ was maintained at 8.0 at the end of the experiment, and the $\mathrm{pH}$ for treatments $\mathrm{A}$ and $\mathrm{B}$ decreased to approximately 7.7. In the early phase of composting, mesophilic microorganisms can rapidly decompose organic matter; nitrification bacteria can turn ammonia and ammonia compounds into nitrate as a result of a decline in $\mathrm{pH}$. Owing to the lack of $\mathrm{O}_{2}$, treatment $\mathrm{C}$ produced more acidic substances during the decomposition of organic matter. Therefore, the $\mathrm{pH}$ of compost produced under treatment $\mathrm{C}$ decreased significantly during the high-temperature period. But from the seventh day to the sixty-third day, the $\mathrm{pH}$ of treatment $\mathrm{C}$ was higher than $\mathrm{A}$ and $\mathrm{B}$, the result was not the same as the result of the Michel Jr and Reddy's (1998) research. At low oxygenation rates $\left(0\right.$ and $\left.0.1 \mathrm{ml} \mathrm{O}_{2} / \mathrm{min}\right)$ composts had a low $\mathrm{pH}(<5.0)$, and high levels of soluble salts $(>7 \mathrm{mS})$, phosphorus, and ammonia. In contrast, at the highest rate of oxygenation (10 $\mathrm{ml} \mathrm{O}_{2} / \mathrm{min}$ ), the final compost had an alkaline $\mathrm{pH}$ (8.6). The reason might be more $\mathrm{NH}_{3}$ emission from treatment $\mathrm{B}$ and A. Statistical analysis shows that the impact of aeration rate on $\mathrm{pH}$ is significant $(\mathrm{p}<0.05)$.

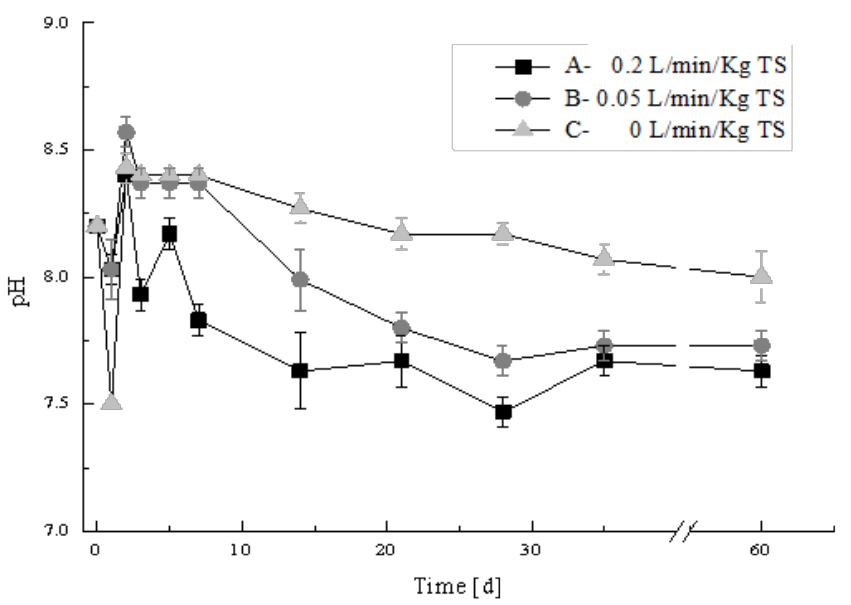

Figure 4. Changes of $\mathrm{pH}$ during composting

As treatment A was the highest aeration rate, more water was removed from the compost and the water content decreased rapidly. At the end of composting, the water content for treatments A, B and C decreased to $39.47 \%, 44.25 \%$ and $49.50 \%$, respectively (Figure 5). Statistical analysis showed that, at the end of composting, the impact of the three treatments on water content was significant $(p<0.05)$. The results were in contrast with the research carried out by Zhou et al.(2014). Zhou et al.(2014) found that after the aeration rate increased to a certain extant, the water removal rate would not increase significantly. But this result showed that the aeration rate was negatively correlated with water content in the compost pile.

\section{3. $\mathrm{NH}_{4}^{+}-\mathrm{N}, \mathrm{NO}_{3}^{-}-\mathrm{N}$ and $\mathrm{NH}_{3}$}

Figure 6 shows that in the early phase of composting, the $\mathrm{NH}_{4}^{+}-\mathrm{N}$ content of each compost pile decreased. Subsequently, the $\mathrm{NH}_{4}^{+}-\mathrm{N}$ content of each compost rose rapidly. On day 5 , the $\mathrm{NH}_{4}^{+}-\mathrm{N}$ content of compost produced under treatments $\mathrm{A}, \mathrm{B}$ and $\mathrm{C}$ reached maximum values of $659 \mathrm{mg} / \mathrm{kg}, 771 \mathrm{mg} / \mathrm{kg}$ and $623 \mathrm{mg} / \mathrm{kg}$, respectively. The $\mathrm{NH}_{4}^{+}-\mathrm{N}$ content in the late high-temperature period showed a significant decreasing trend with each treatment. At the end of 60 days of composting, the $\mathrm{NH}_{4}^{+}-\mathrm{N}$ content for each treatment was above $25 \mathrm{mg} / \mathrm{kg}$. According to the study of Bernal et al. (1998), at the end of composting, when $\mathrm{NH}_{4}^{+}$$\mathrm{N}$ content is lower than $0.4 \mathrm{~g} / \mathrm{kg}$, compost can be considered to have reached maturity. Statistical analysis showed that 
the differences in $\mathrm{NH}_{4}^{+}-\mathrm{N}$ content for the three treatments are not significant $(\mathrm{p}>0.05)$.

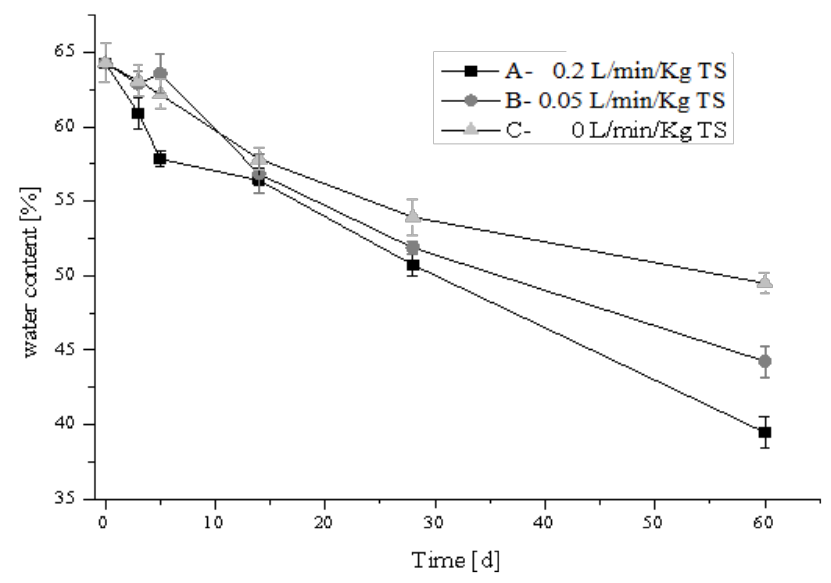

Figure 5. Changes of water content during composting

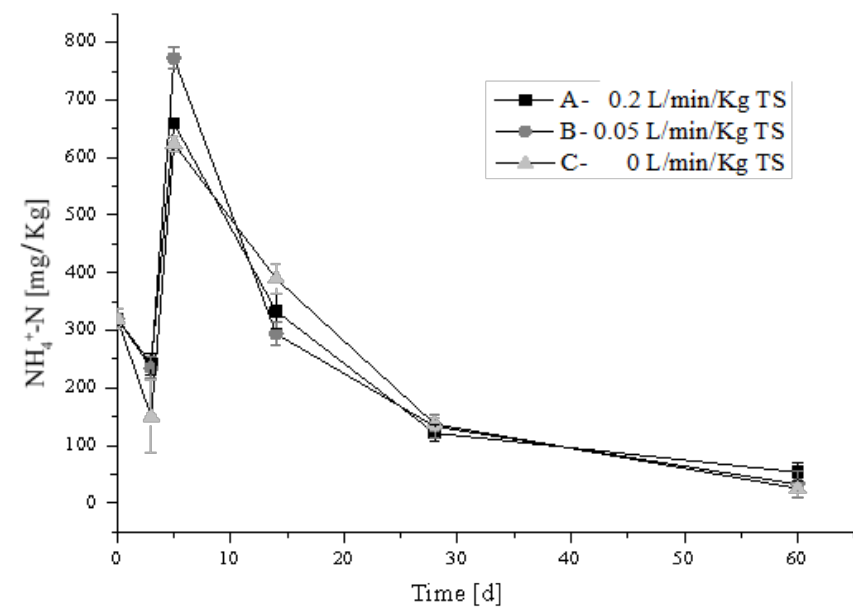

Figure 6. Changes of $\mathrm{NH}_{4}^{+}-\mathrm{N}$ during composting

During the warming period, the $\mathrm{NO}_{3}^{-}-\mathrm{N}$ content of compost produced under treatment $\mathrm{A}, \mathrm{B}$, and $\mathrm{C}$ decreased to $375.9 \mathrm{mg} / \mathrm{kg}, 155.8 \mathrm{mg} / \mathrm{kg}$ and $254.1 \mathrm{mg} / \mathrm{kg}$, respectively (Figure 7). After the warming period, the $\mathrm{NO}_{3}^{-}-\mathrm{N}$ content of all composts increased. At the end of composting, the $\mathrm{NO}_{3}^{-}$$\mathrm{N}$ content of composts produced under treatments $\mathrm{A}$ and $\mathrm{B}$ were $816 \mathrm{mg} / \mathrm{kg}$ and $710 \mathrm{mg} / \mathrm{kg}$, respectively. However, the $\mathrm{NO}_{3}^{-}-\mathrm{N}$ content of compost produced under treatment $\mathrm{C}$ was only $510 \mathrm{mg} / \mathrm{kg}$. These results showed that treatments A and $\mathrm{B}$, owing to the supply of oxygen, may be more conducive to the generation of $\mathrm{NO}_{3}^{-}-\mathrm{N}$. Statistical analysis showed that the differences in $\mathrm{NO}_{3}^{-}-\mathrm{N}$ content for the three treatments were significant after the fourteenth day $(\mathrm{p}<0.05)$.

Figure 8 shows that the $\mathrm{NH}_{3}$ emission trends of composts produced under treatments A and B were consistent. During the high-temperature period, the $\mathrm{NH}_{3}$ emissions for treatments $\mathrm{A}$ and $\mathrm{B}$ reached their maximum values of 38.25 $\mathrm{mg} / \mathrm{h}$ and $14.03 \mathrm{mg} / \mathrm{h}$, respectively. The result showed that the peak of $\mathrm{NH}_{3}$ emissions coincided with the maximum of temperature and oxygen uptake rate, and was confirmed by

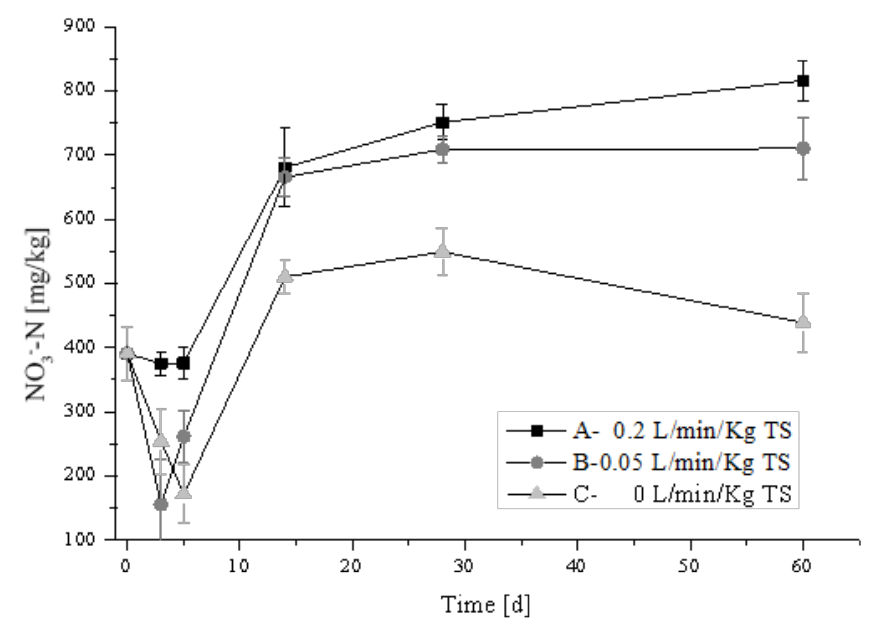

Figure 7. Changes of $\mathrm{NO}_{3}^{-}-\mathrm{N}$ during composting

previous studies by Pagans et al. (2006) and de Guardia et al. (2008). Then $\mathrm{NH}_{3}$ emissions declined with the decomposition of organic matter and strengthening of nitrification. During the late phase of composting, $\mathrm{NH}_{3}$ emissions were close to zero. $\mathrm{NH}_{3}$ emissions from compost produced under treatment $\mathrm{C}$ was very low during the whole composting phase and was only $0.85 \mathrm{mg} / \mathrm{h}$ during the high-temperature period. The aeration strategy used influences gaseous emissions during composting. This result is consistent with a previous study, which observed that $\mathrm{NH}_{3}$ emissions increased with higher aeration rates (Shen et al., 2011). The findings of Shen et al. (2011) and Chowdhury et al. (2014) are also in agreement with those of other authors.

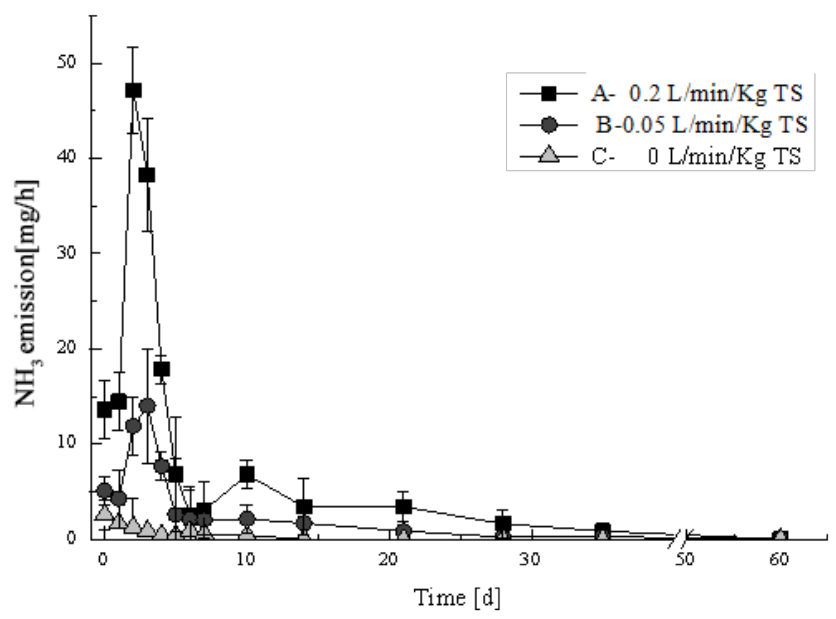

Figure 8. Changes of $\mathrm{NH}_{3}$ during composting

In the early composting phase, mesophilic microorganisms can rapidly decompose organic matter, and nitrification bacteria can turn ammonia and ammonia compounds into $\mathrm{NO}_{3}^{-}$, causing declines in the $\mathrm{pH}$ and $\mathrm{NH}_{4}^{+}-\mathrm{N}$ content and increases in the $\mathrm{NO}_{3}^{-}-\mathrm{N}$ content of each compost. Treatment A had the highest aeration rate; therefore, the loss of $\mathrm{NH}_{4}^{+}-\mathrm{N}$ in the form of $\mathrm{NH}_{3}$ was greatest under these conditions. Recently, a design has been suggested that includes a compost bio-filter for the capture of $\mathrm{NH}_{3}$ emissions and their 
conversion to $\mathrm{NO}_{3}^{-}$during manure digestion (Posmanik et al., 2013).

When Michel Jr and Reddy (1998) researched the impact of different $\mathrm{O}_{2}$ replenishment amounts on compost, they found that $\mathrm{NH}_{3}$ emissions increased when the $\mathrm{O}_{2}$ replenishment amount increased. This is consistent with the results of our study. Figure 8 shows that aeration rate has a major impact on $\mathrm{NH}_{3}$ emissions in the early phase of composting. Jiang et al. (2011) also found that aeration rate was the most important factor which could affect the $\mathrm{NH}_{3}$.

\subsection{TOC/TN, TOC and TN}

The carbon to nitrogen ratio (TOC/TN) showed a clearly decreasing trend from initial values of approximately 21 to final values of $12.41,12.97$, and 13.67 for compost produced under treatments A, B, and C, respectively (Figure 9). In each pile, this ratio decreased slowly throughout the composting process. The final TOC/TN ratios were an indication of compost stability and compost maturity, and they were between 10:1 and 15:1 for the final composts (Ogunwande and Osunade, 2011). The initial TOC/TN ratios were consistent with values determined by Rasapoor et al. (2009) for a wide range of organic wastes, while final values for the three piles were lower than 20 , which is thought to be the threshold limit for compost maturity. The low $\mathrm{C} / \mathrm{N}$ ratio of the final compost was mainly a result of the degradation of the organic carbon (Zhu, 2007).

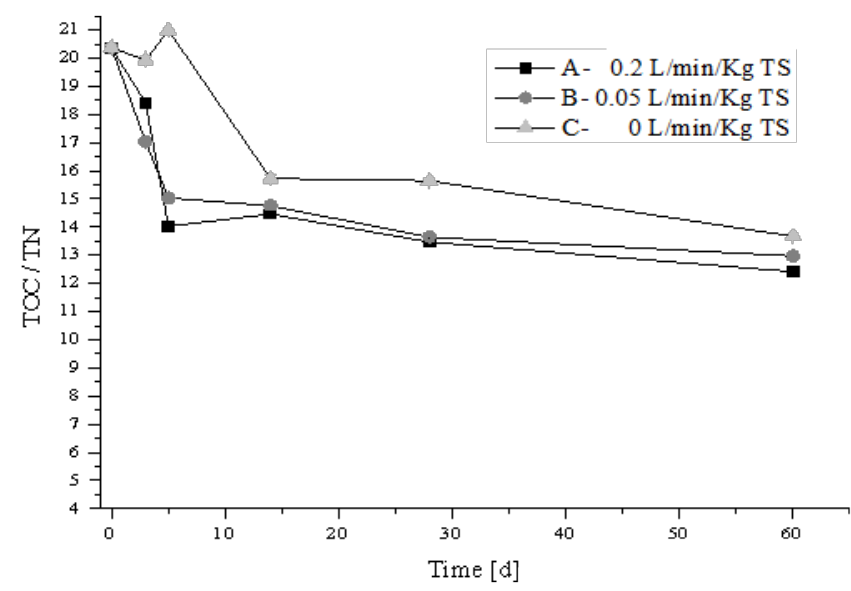

Figure 9. Changes of TOC/TN during composting

Throughout the entire composting process, the total organic carbon (TOC) of all composts declined (Figure 10). In the early composting phase, TOC decreased significantly for all treatments. At fifth day, the TOC content of compost produced under treatments A, B and C decreased to 216.89 $\mathrm{g} / \mathrm{kg}, 258.89 \mathrm{~g} / \mathrm{kg}$ and $316.80 \mathrm{~g} / \mathrm{kg}$, respectively, from the initial $389.91 \mathrm{~g} / \mathrm{kg}$. During the cooling period, the TOC content change for each treatment was smooth. At the end of composting, the TOC content for treatment A was slightly lower than B or C, and the TOC contents for treatments A, $\mathrm{B}$ and $\mathrm{C}$ decreased to $249.79 \mathrm{~g} / \mathrm{kg}, 264.41 \mathrm{~g} / \mathrm{kg}$ and 265.63 $\mathrm{g} / \mathrm{kg}$, respectively. As seen from our results, the influence of ventilation on the TOC content change during the composting process was not significant.

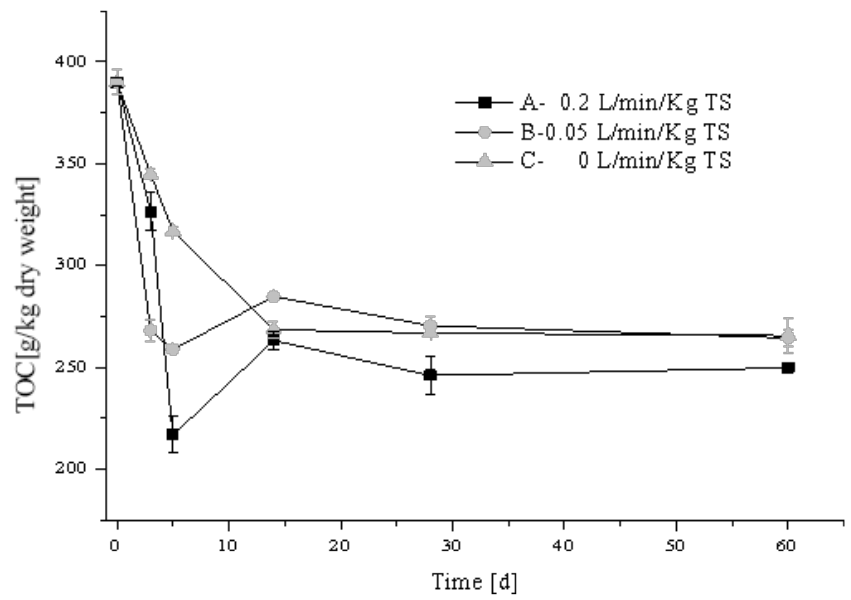

Figure 10. Changes of TOC during composting

Total nitrogen content (TN) is a significant indicator of the fertilizer efficiency of compost products. Figure 11 shows the changes in TN during composting with each treatment: TN decreased at the beginning of composting, then increased. During the high-temperature phase, the minimum TN for treatments A, B, and C declined from 19.15 $\mathrm{g} / \mathrm{kg}$ to approximately $15 \mathrm{~g} / \mathrm{kg}$ at the fifth, third and fifth days, respectively. During the composting process, the loss of $\mathrm{CO}_{2}$ and the microbial mineralization of organic matter led to a reduction in dry matter content; this was greater than the loss of TN. At the end of composting, the TN had increased; the TN of compost produced under treatment $\mathrm{B}$ $(20.38 \mathrm{~g} / \mathrm{kg})$ was greater than that of treatments $\mathrm{C}(19.43$ $\mathrm{g} / \mathrm{kg})$ or $\mathrm{A}(20.12 \mathrm{~g} / \mathrm{kg})$. Figure 11 shows that the increase in $\mathrm{TN}$ for treatment $\mathrm{C}$ was larger than the loss of nitrogen.

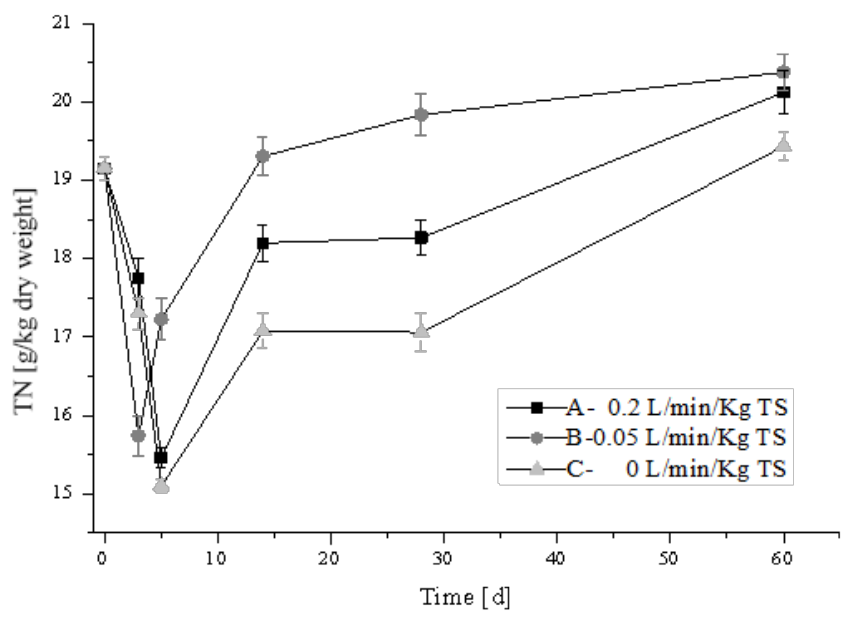

Figure 11. Changes of TN during composting

\subsection{Nitrogen Loss Under Different Treatments}

The nitrogen loss measurements for compost generated under the three different aeration rates are shown in Table 2. 
Table 2. The loss of nitrogen during composting with different aeration rate

\begin{tabular}{|c|c|c|c|c|c|c|}
\hline Treatment & Initial TN & Final TN & $\begin{array}{l}\text { Nitrogen } \\
\text { loss }\end{array}$ & $\begin{array}{l}\text { Nitrogen } \\
\text { loss rate }\end{array}$ & $\begin{array}{c}\mathrm{NH}_{3} \\
\text { emission }\end{array}$ & $\begin{array}{c}\mathrm{NH}_{3} \text { emission } \\
\text { rate }\end{array}$ \\
\hline & $(\mathrm{g} / \mathrm{kg} \mathrm{VS})$ & $(\mathrm{g} / \mathrm{kg} \mathrm{VS})$ & (g/kg VS) & $(\%)$ & $(\mathrm{g} / \mathrm{kg} \mathrm{VS})$ & $(\%)$ \\
\hline $\mathrm{A}$ & 437.78 & 409.28 & 28.5 & 6.51 & 5.81 & 20.38 \\
\hline B & 437.78 & 418.39 & 19.39 & 4.43 & 1.91 & 9.85 \\
\hline $\mathrm{C}$ & 437.78 & 434.11 & 3.68 & 0.84 & 0.21 & 5.71 \\
\hline
\end{tabular}

Note: Nitrogen loss rate: Nitrogen loss/Initial TN.

$\mathrm{NH}_{3}$ emission rate: $\mathrm{NH}_{3}$ emission/Nitrogen loss.

The nitrogen loss for treatment A was the largest and the total amount of nitrogen lost (in the form of $\mathrm{NH}_{3}$ emissions) was $20.38 \%$. The $\mathrm{NH}_{3}$ emission rates for treatments $\mathrm{A}$ and $\mathrm{B}$ accounted for $9.85 \%$ and $5.71 \%$ of nitrogen loss, respectively. The amounts of nitrogen lost and the rate of nitrogen loss with treatment $\mathrm{C}$, for which the aeration rate was $0 \mathrm{~L} / \mathrm{kg} / \mathrm{min}$, were $3.68 \mathrm{~g}$ and $0.84 \%$, respectively. This result indicates that $\mathrm{NH}_{3}$ emissions are influenced by aeration rates. Statistical analysis shows that the aeration rate has a significant effect on nitrogen loss and $\mathrm{NH}_{3}$ emissions from compost. The results for treatments $\mathrm{A}$ and $\mathrm{B}$ were similar to those of Guo et al. (2012). Higher aeration rates can cause higher nitrogen losses.

\subsection{Seed Germination Rate}

The seed germination index (GI) is an important factor in judging the maturity of compost. The composting process produces large amounts of substances that are toxic to plants, and the amounts of these toxic substances are gradually reduced as the compost matures is increased (Hase and Kawamura, 2012). When the seeds germinate with a GI greater than $50 \%$, the compost is considered to be mature (Zucconi et al., 1981). On the sixty-third day, the GIs of composts produced under treatments $\mathrm{A}, \mathrm{B}$, and $\mathrm{C}$ were $53.54 \%, 64.81 \%$, and $39.51 \%$, respectively, and on day 0 , the GI of the feedstock was $18.56 \%$ (Figure 12). Thus, treatments $\mathrm{A}$ and $\mathrm{B}$ produced mature compost, but treatment $\mathrm{C}$ (static composting) did not. Increasing dissolved oxygen is an important factor in achieving successful aerobic composting. Ventilation is one of the main measures used to increase dissolved oxygen. Treatments A and B can promote sufficient contact between the compost medium and the air to provide oxygen for the aerobic microorganisms, thus increasing microbial activity and accelerating maturation. Statistical analysis showed that ventilation could significantly affect the seed germination index $(\mathrm{p}<0.05)$.

\section{Conclusion}

The present study suggested that different aeration rates had a significant impact on temperature during the hightemperature period of composting. The ventilation rate significantly influenced the water content, $\mathrm{pH}, \mathrm{NO}_{3}^{-}-\mathrm{N}$, and nitrogen loss of samples. The cumulative volatilization of $\mathrm{NH}_{3}$ increased with an increase in the aeration rate: a higher

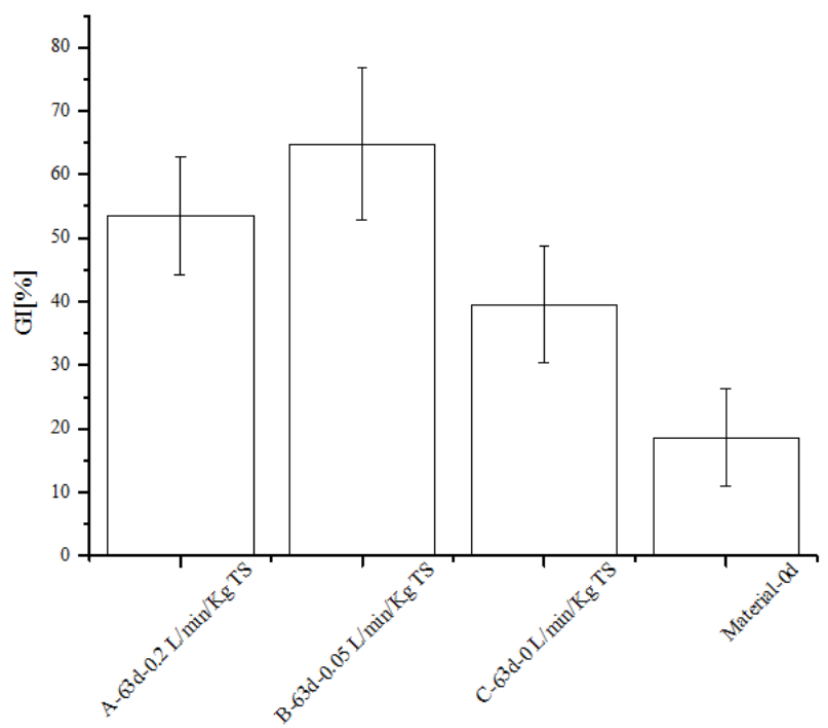

Note: Values were averages of three replicates \pm SD.

Figure 12. Seed germination rate of different sample of compost

aeration rate led to a higher $\mathrm{NH}_{3}$ emission rate. The ventilation method could improve the degree of fertilizer maturity and therefore increase GI.

Based on our research, we hold the opinion that proper ventilation can increase the nitrogen content to increase the quality of the compost when static aeration technology is used for composting, and we recommend that the optimal ventilation quantity is about one time volume of fermentation heap. In the future, the relationship of carbon loss and nitrogen loss should be carried out during the composting.

\section{Author Contributions}

Z-Q Xiong and G-X Wang contributed equally to this work. W-D Wang and J-D Gu designed the experiment. Z-Q Xiong, G-X Wang and Z-C Huo carried out experiment of composting. G-X Wang, Z-Q Xiong and Z-C Huo measured the physicochemical parameters of compost sample. G-X Wang, Z-Q Xiong and W-D Wang carries on the statistical analysis to the measured data. G-X Wang, Y Li, Z-Q Xiong and Z-C Huo wrote the paper. W-D Wang, L Yan, J-D Gu, Y-M Gao, and Y-J Wang gave the comments on the draft of the article. All of us comments on the final manuscript. 


\section{Conflict of Interest and Funding}

No conflict of interest was reported by the authors.

\section{Acknowledgments}

This work was supported by the National Natural Science Foundation of China (31270536), Key Projects in the National Science \& Technology Pillar Program during the Twelfth Five-Year Plan Period (Grant No. 2012BAD12B053, 2016YFD0800602), Central local development science and technology special project (ZY16A04-02), Program of Science and Technology Innovation Teams Building in Heilongjiang Province (2012TD006), Key Science and Technology Program of Heilongjiang Province (GC12B306), and Key Science, Technology Program of Heilongjiang Agricultural Company (HNK135-04-08, JCTG17-04) and Heilongjiang Bayi Agricultural University graduate innovation project (YJSCX2016-Y47).

\section{References}

Ahn, H.K., Mulbry, W., White, J.W. and Kondrad, S.L., 2011. Pile mixing increases greenhouse gas emissions during composting of dairy manure. Bioresource Technology, 102(3), 2904-2909. https://doi.org/10.1016/j.biortech.2010.10.142.

Bernal, M.P., Paredes, C., Sánchez-Monedero, M.A. and Cegarra, J., 1998. Maturity and stability parameters of composts prepared with a wide range of organic wastes. Bioresource Technology, 63(1), 91-99.

https://doi.org/10.1016/S0960-8524(97)00084-9.

Bes, C.M., Jaunatre, R. and Mench, M., 2013. Seed bank of $\mathrm{Cu}$-contaminated topsoils at a wood preservation site: impacts of copper and compost on seed germination. Environmental Monitoring and Assessment, 185(2), 2039-2053.

https://doi.org/10.1007/s10661-012-2686-x.

Chowdhury, M.A., de Neergaard, A. and Jensen, L.S., 2014. Potential of aeration flow rate and bio-char addition to reduce greenhouse gas and ammonia emissions during manure Composting. Chemosphere, 97(1), 16-25.

https://doi.org/10.1016/j.chemosphere.2013.10.030.

de Guardia, A., Petiot, C., Rogeau, D. and Druilhe, C., 2008. Influence of aeration rate on nitrogen dynamics during composting. Waste Management, 28(3), 575-587.

https://doi.org/10.1016/j.wasman.2007.02.007.

El-Nagerabi, S.A.F., Elshafie, A.E. and AlRawahi, H.S., 2012. Physicochemical and microbial characteristics of locally processed green waste composts. Compost Science and Utilization, 20(2), 120-127.

https://doi.org/10.1080/1065657X.2012.10737034.

Gao, D., Zheng, Y.Q., Chen, T.B., Lei, M., Zheng, Y.M., Zheng, G.D. and Luo, W., 2007. Profile characteristics of oxygen concentration during aerobic composting of pig manure. Journal of Agro-Environment Science, 26(6), 2189- 2194.

Grunditz, C. and Dalhammar, G., 2001. Development of nitrification inhibition assays using pure cultures of nitrosomonas and nitrobacter. Water Resource, 35(2), 433-440.

https://doi.org/10.1016/S0043-1354(00)00312-2.

Gu, W., Zhang, F., Xu, P., Tang, S., Xie, K., Huang, X. and Huang, Q., 2011. Effects of sulphur and thiobacillus thioparus on cow manure aerobic composting. Bioresource Technology,
102(11), 6529-6535.

https://doi.org/10.1016/j.biortech.2011.03.049.

Guo, R., Li, G., Jiang, T., Schuchard, F., Chen, T., Zhao, Y. and Shen, Y., 2012. Effect of aeration rate, $\mathrm{C} / \mathrm{N}$ ratio and moisture content on the stability and maturity of compost. Bioresource Technology, 112(58), 171-178.

https://doi.org/10.1016/j.biortech.2012.02.099.

Hase, T. and Kawamura, K., 2012. Germination test on komatsuna (Brassica rapa var. peruviridis) seed using water extract from compost for evaluating compost maturity: evaluating criteria for germination and effects of cultivars on germination rate. Journal of Material Cycles \& Waste Management, 14(4), 334-340.

Jiang, T., Schuchardt, F., Li, G.X., Guo, R. and Zhao, Y.Q., 2011. Effect of $\mathrm{C} / \mathrm{N}$ Ratio, Aeration rate and water content on ammonia and greenhouse gas emission during the composting. Environment Science, 23(10), 1754-1760.

https://doi.org/10.1016/S1001-0742(10)60591-8.

Michel Jr, F.C. and Reddy, C.A., 1998. Effect of oxygenation level on yard trimmings composting rate, odor production and compost quality in bench-scale reactors. Compost Science and Utilization, 6(4), 6-14.

https://doi.org/10.1080/1065657X.1998.10701936.

Ogunwande, G.A. and Osunade, J.A., 2011. Passive aeration composting of chicken litter: effects of aeration pipe orientation and perforation size on losses of compost elements. Journal of Environmental Management, 92(1), 85-91.

https://doi.org/10.1016/j.jenvman.2010.08.026.

Pagans, E., Barrena, R., Font, X. and Sanchez, A., 2006. Ammonia emissions from the composting of different organic wastes. Dependency on process temperature. Chemosphere, 62(9), 15341542.

https://doi.org/10.1016/j.chemosphere.2005.06.044.

Posmanik, R., Nejidat, A., Bar-Sinay, B. and Gross, A., 2013. Integrated biological treatment of fowl manure for nitrogen recovery and reuse. Journal of Environmental Management, 117, 172179.

https://doi.org/10.1016/j.jenvman.2012.12.049.

Rasapoor, M., Nasrabadi, T., Kamali, M. and Hoveidi, H., 2009. The effects of aeration rate on generated compost quality, using aerated static pile method. Waste Management, 29(2), 570-573. https://doi.org/10.1016/j.wasman.2008.04.012.

Scaglia, B., Orzi, V., Artola, A., Font, X., Davoli, E., Sanchez, A. and Adani, F., 2011. Odours and volatile organic compounds emitted from municipal solid waste at different stage of decomposition and relationship with biological stability. Bioresource Technology, 102 (7), 4638-4645.

https://doi.org/10.1016/j.biortech.2011.01.016.

Shen, Y.J., Ren, L.M., Li, G.X., Chen, T.B. and Guo, R., 2011. Influence of aeration on $\mathrm{CH}_{4}, \mathrm{~N}_{2} \mathrm{O}$ and $\mathrm{NH}_{3}$ emissions during aerobic composting of a chicken manure and high $\mathrm{C} / \mathrm{N}$ waste mixture. Waste Management, 31(1), 33-38.

https://doi.org/10.1016/j.wasman.2010.08.019.

Sims, G.K., Ellsworth, T.R. and Mulvaney, R.L., 1995. Microscale determination of inorganic nitrogen in water and soil extracts. Communications in Soil Science and Plant Analysis, 26(12), 303-316. https://doi.org/10.1080/00103629509369298.

Wu, C.F., Wang, Q.H., Sun, X.H., Xue, N.T., Liu, S. and Xie, W.M., 2011. Effect of aeration modes on the characteristics of composting emissions and the $\mathrm{NH}_{3}$ removal efficiency by using biotrickling filter. Waste Management, 31(8), 1702-1710.

https://doi.org/10.1016/j.wasman.2011.04.003. 
Yu, H.Y., Zeng, G.M., Huang, H.L., Xi, X.M., Wang, R.Y., Huang, D.L., Huang, G.H. and Li, J.B., 2007. Microbial community succession and lignocellulose degradation during agricultural waste composting. Biodegradation, 18(6), 793-802.

https://doi.org/10.1007/s10532-007-9108-8.

Zeng, G.M., Yu, Z., Chen, Y.N., Zhang, J.C., Li, H., Yu, M. and Zhao, M.J., 2011. Response of compost maturity and microbial community composition to pentachlorophenol(PCP) - contaminated soil during composting. Bioresource Technology, 102(10), 5905-5911.

https://doi.org/10.1016/j.biortech.2011.02.088.
Zhou, H.B., Chen, T.B., Gao, D., Zheng, G.D., Chen, J., Pan, T.H., Liu, H.T. and Gu, R.Y., 2014. Simulation of water removal process and optimization of aeration strategy in sewage sludge composting. Bioresource Technology, 171, 452-460. https://doi.org/10.1016/j.biortech.2014.07.006.

Zhu, N., 2007. Effect of low initial C/N ratio on aerobic composting of swine manure with rice straw. Bioresource Technology, 98(1), 913.

https://doi.org/10.1016/j.biortech.2005.12.003.

Zucconi, F., Pera, A., Forte, M. and De Bertoldi, M., 1981. Evaluating toxicity of immature compost. Biocycle, 22(2), 54-57. 